\title{
SYNTHESIS AND ANTICANCER ACTIVITY OF IMIDAZOLE DERIVATIVES INCORPORATING CHROMENE MOIETY
}

\author{
Nashwa M. Saleh \\ Department of Chemistry, Faculty of Science (Girl's), Al-Azhar University, Nasr City, Cairo, Egypt
}

\begin{abstract}
The oxo-chromene-6-carbaldehyde derivative $\mathbf{1}$ was used as a starting material for the synthesis of some novel pyrano[3,2-b] xanthene-4,7-dione 2 and chromen-oxazol-5$(4 H)$-one derivatives 4,5. Furthermore, the oxazolone derivative 4 was used as key intermediates to synthesize some novel imidazol derivatives 6-14. The structures of target compounds were confirmed by elemental analyses and spectral data. All the target compounds were subjected to in-vitro antitumor activity against breast and colon human tumor cell lines (MCF7 and HCT). Most of the screened compounds showed interesting cytotoxic activities compared to a reference drug.
\end{abstract}

Kerwords: Chromene, Oxazolone, Imidazole, Antitumor activity.

\section{INTRODUCTION}

In recent years, the high therapeutic properties of the imidazole related drugs have been attracting the attention the medicinal chemists to synthesize a large number of novel chemotherapeutic agents. Imidazole drugs have broadened scope in remedying various dispositions in clinical medicines. Medicinal properties of imidazole containing compounds include anticancer (Congio, et al., 2008), antimicrobial, (Aridoss, et al., 2006; Nagarapu, et al., 2008), antibacterial, (Bhandari, et al., 2009) antifungal, (Emami, et al., 2008) and antioxidant (Smith and Reeves, 1987; Bakr, et al., 2011). Encouraged by these observations and in continuation of our previous work to discover new biologically active heterocyclic compounds (Abdel-Aziz, et al., 2010; Abdalla, et al., 2009; Amr, et al., 2009; AbdeWahab, et al., 2009a; Abde-Wahab, et al., 2009b; Abde-Wahab, et al., 2009c). Lepidiline A and B are the imidazole compounds which exhibit cytotoxicity against various types of human cancer cell line sat micro molar concentrations (Cui, et al., 2003). In addition to imidazole, some other azole and benzazole ring systems such as benzoxazole, benzothiazole, triazole, tetrazole, thiadiazole and thiazoline can be shown as pharmacophore groups which are responsible for the anticancer activity (Kumar, et al., 2002; Hose, et al., 2003; Al-Masoudi, et al., 2006; Perez-Ruixo, et al., 2006; Ozkay, et al., 2010; Padmavathi, et al., 2011). We now tried to apply the Erlenmeyer-Ploechl azalactone synthesis (Erlenmeyer and Liebigs, 1893). This latter reaction has often been used with the aim of synthesizing fused pyran-2-ones by combining condensation, with lactonization. For this reason simple one-pot procedures have been developed using 1,3-dicarbonyl compounds, one-carbon synthon (triethylorthoformate, or $N, N$-dimethylformamide dimethylacetal) $N$-acetyl glycine and large excess of acetic anhydride (Kepe, et al., 1992). Another approach for these reactions made use of a two steps synthesis incorporating the one-carbon synthon either in the $\mathrm{CH}$-acidic compound (Kepe, et al., 1999) or in the azalactone (Nulwad and Shirodkar, 2002). The present study was provoked by the paper of Mulwad and Shirodkar describing the condensation of 3-formyl-4-hydr-oxycoumarin with hippuric acid or $\mathrm{N}$-acetylglycine to form 3-acylamino-2, 5-dioxo-pyrano[3,2-c] benzopyrans (Ivanov, et al., 2005). 


\section{RESULT AND DISCUSSION}

\section{Chemistry}

The synthetic procedures adopted to obtain the target new compounds are showed in Schemes 1-5. Treatment of 7-hydroxy-5-methoxy-2-methyl-4-oxo-4H-chromene-6carbaldehyde (Kepe, et al., 1993) 1 with cyclic active methylene as 5,5dimethylcyclohexane-1,3-dione yielded the condensation product 5-methoxy-2,9,9trimethyl-8,9,10,10a-tetrahydropyrano[3,2-b]xanthene-4,7-dione 2 . The formation of compound $\mathbf{2}$ is assumed to proceed through the in situ intramolecular cyclization of the non isolable intermediate via nucleophilic addition of the hydroxyl group to the carbonyl group followed by elimination of water, Scheme 1. Structure of compound $\mathbf{2}$ was confirmed on the basis of elemental analysis and spectral data. IR spectrum of compound 2 revealed the absence of aldehyde and hydroxyl groups, the carbonyl stretching frequency was observed at $1657 \mathrm{~cm}^{-1}$ and the coumarin carbonyl stretching at $1723 \mathrm{~cm}^{-1}$. Also, the ${ }^{1} \mathrm{HNMR}$ spectrum indicated the presence of a singlet at $\ddot{a} 1.17 \mathrm{ppm}$ due to $\mathrm{C}_{9}-2 \mathrm{CH}_{3}$ protons. $\mathrm{The}_{2} \mathrm{C}_{2}-\mathrm{CH}_{3}$ protons were observed a singlet at $2.29 \mathrm{ppm}$. The $\mathrm{C}_{10}-\mathrm{CH}_{2}$ and $\mathrm{C}_{8}-\mathrm{CH}_{2}$ protons were observed a singlet at $1.5,2.9 \mathrm{ppm}$. The $\mathrm{C}_{5}-\mathrm{OCH}_{3}$ protons were observed downfield as singlet at $4.23 \mathrm{ppm}$. The $\mathrm{C}_{3,6,12}-\mathrm{H}$ of coumarin protons resonated in the range of 6.13-7.79 ppm. Also, the structure 2 was supported by its mass spectrum which revealed a molecular ion peak at $\mathrm{m} / \mathrm{z} 340(9.72 \%)$ corresponding to the molecular formula $\mathrm{C}_{20} \mathrm{H}_{20} \mathrm{O}_{5}$.

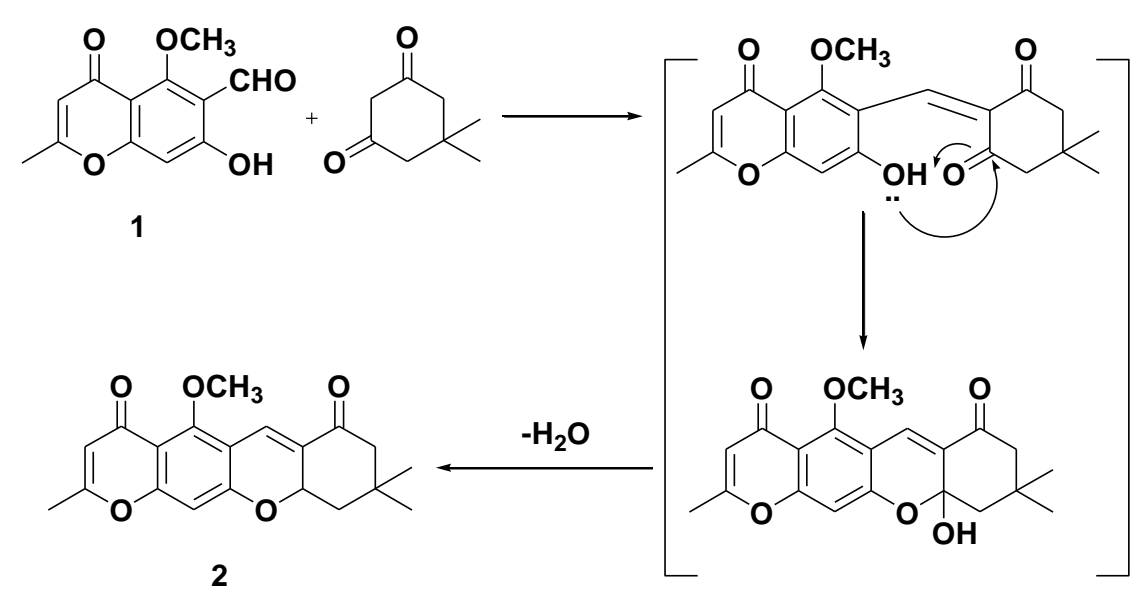

Scheme 1. Expected scheme for the synthesis of xanthene-4,7-dione derivative from chromene-carbaldehyde .

The present study was provoked by the paper of Mulwad (Ivanov, et al., 2005) 1 which reacted with o-chlorobenzoylglycine and acetylglycine $\mathbf{3 a}, \mathbf{b}$ in acetic acid/acetic anhydride in presence of fused sodium acetate under reflux afforded 2-(2-chlorophenyl)-4((7-hydroxy-5-methoxy-2-methyl-4-oxo-4H-chromen-6-yl)methylene)oxazol-5(4H)-one and 4-((7-hydroxy-5-methoxy-2-methyl-4-oxo-4H-chromen-6-yl)methylene)-2-methyl-oxazol-5$(4 H)$-one 4,5, respectively. Scheme 2 . The intermediates could not be isolated and underwent spontaneous recyclization via opening of the azalactone ring and formed the fused 2(lH)-pyridone ring. Compounds $\mathbf{4}, \mathbf{5}$ confirmed by IR spectra which revealed the oxazol carbonyl stretching frequency at $1703,1710 \mathrm{~cm}^{-1}$, where as the coumarin carbonyl stretching at $1619,1617 \mathrm{~cm}^{-1}$, while it showed the presence of broad band for $\mathrm{OH}$ group stretching at $3423,3363 \mathrm{~cm}^{-1}$ respectively. Structures 4, 5 were supported by its mass and ${ }^{1} \mathrm{H}$ NMR spectra. ${ }^{1} \mathrm{H}$ NMR (DMSO- $d_{6}, 300 \mathrm{MHz}$ ) of 4 raveled a singlet was observed at $2.26 \mathrm{ppm}$ due to $\mathrm{C}_{2}-\mathrm{CH}_{3}$ protons. The $\mathrm{C}_{5}-\mathrm{OCH}_{3}$ protons were observed downfield as singlet at $3.91 \mathrm{ppm}$. 
The $\mathrm{C}_{3,8}-\mathrm{H}$ of coumarin, $\mathrm{CH}=$ and $\mathrm{CH}$-aromatic were resonated in the range of $\ddot{a}$ 6.13-8.19 ppm.
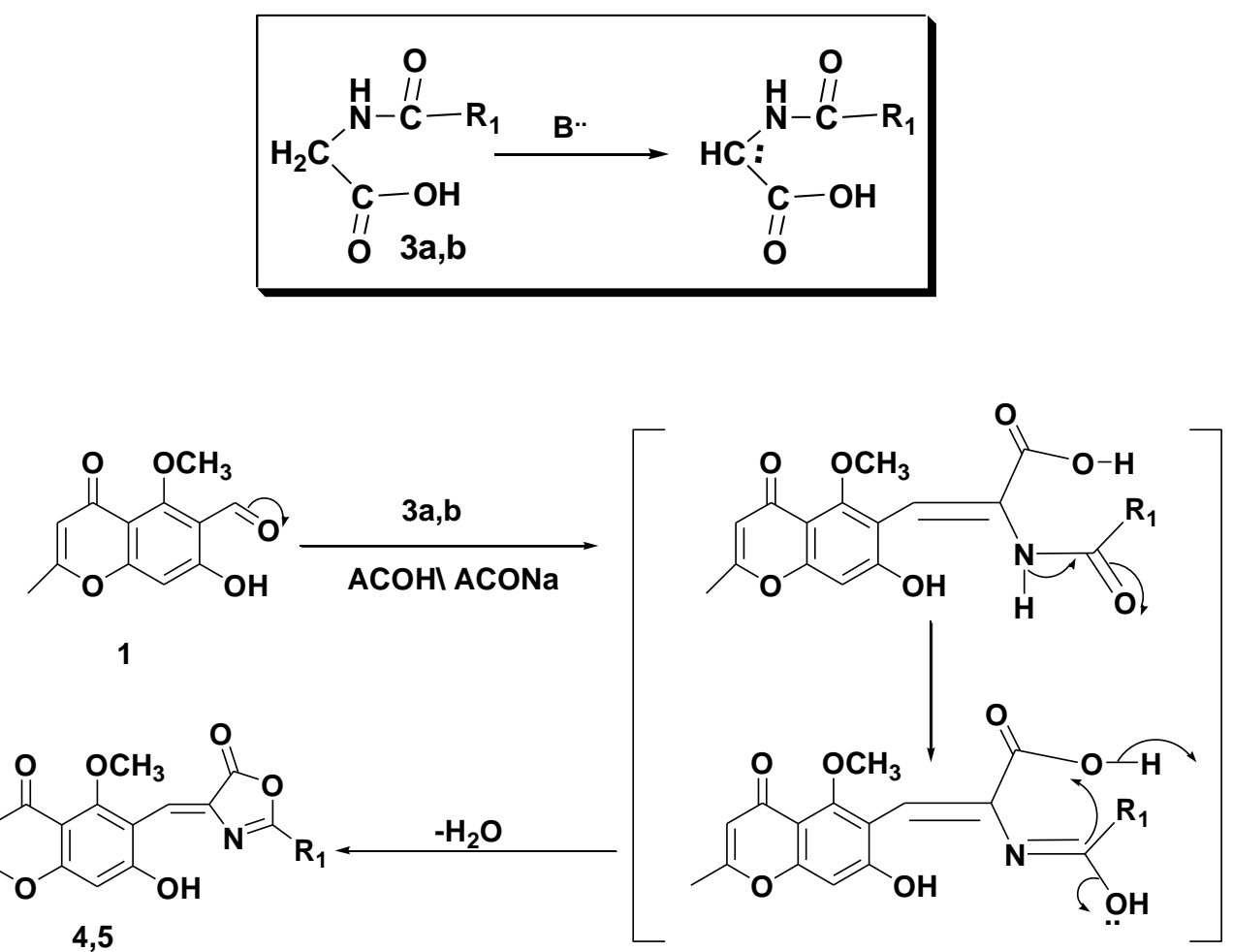

4, $\mathrm{R}_{1}=2-\mathrm{CIC}_{6} \mathrm{H}_{4}$

$5, \mathrm{R}_{1}=\mathrm{CH}_{3}$

Scheme 2. Expected scheme for the synthesis of oxazole derivatives from chromene-6carbaldehyde.

$\mathrm{OH}$ proton was observed as singlet at $11.34 \mathrm{ppm}$. Its mass spectrum which revealed a molecular ion peak at $\mathrm{m} / \mathrm{z} 411(\mathrm{M}-1,5.16 \%)$ corresponding to the molecular formula $\mathrm{C}_{21} \mathrm{H}_{14} \mathrm{ClNO}_{6} .{ }^{1} \mathrm{H}$ NMR (DMSO- $d_{6}, 300 \mathrm{MHz}$ ) of 5 raveled a singlet was observed at 2.23 ppm due to $\mathrm{C}_{2}-\mathrm{CH}_{3}$ protons. The $\mathrm{CH}_{3}$ protons of oxazolone were observed a singlet at 3.41 ppm. The $\mathrm{C}_{5}-\mathrm{OCH}_{3}$ protons were observed downfield as singlet at $\ddot{a} 3.89 \mathrm{ppm}$. The $\mathrm{C}_{3,8}-\mathrm{H}$ of coumarin and $\mathrm{CH}=$ were resonated in the range of $\ddot{a} 6.53-8.21 \mathrm{ppm}$. The $\mathrm{OH}$ proton was observed as singlet at $11.26 \mathrm{ppm}$. Its mass spectrum which revealed a molecular ion peak at $\mathrm{m} / \mathrm{z} 315(6.04 \%)$ corresponding to the molecular formula $\mathrm{C}_{16} \mathrm{H}_{13} \mathrm{NO}_{6}$. Oxazolone derivative 4 was used as intermediate for the synthesis of the some imidazole derivatives via its reaction with some aromatic and hetero aromatic amines. Thus, Oxazolone derivative 4 reacted with 4-aminoacetophenone, 7-aminothiophenol, sulfaquionoxaline , 2-amino-4hydroxypyrimidine and 4-aminoantipyrine in glacial acetic acid in presence of fused sodium acetate to yield yield 2-(2-chlorophenyl)-4-(7-hydroxy-5-methoxy-2-methyl-4-oxo-4Hchromen-6-yl)methylene)-1-(4-aryl)-1H-imidazol-5(4H)-one 6-10, respectively, (Scheme 3 ). The structure of compounds 6-10 were confirmed by their IR, ${ }^{1} \mathrm{HNMR}$ and Mass spectra. The IR spectra revealed the imidazol carbonyl stretching frequency and the coumarin carbonyl stretching with addition special group for each compounds, its mass spectrum and ${ }^{1} \mathrm{H}$ NMR spectra respectively in experimental section. 


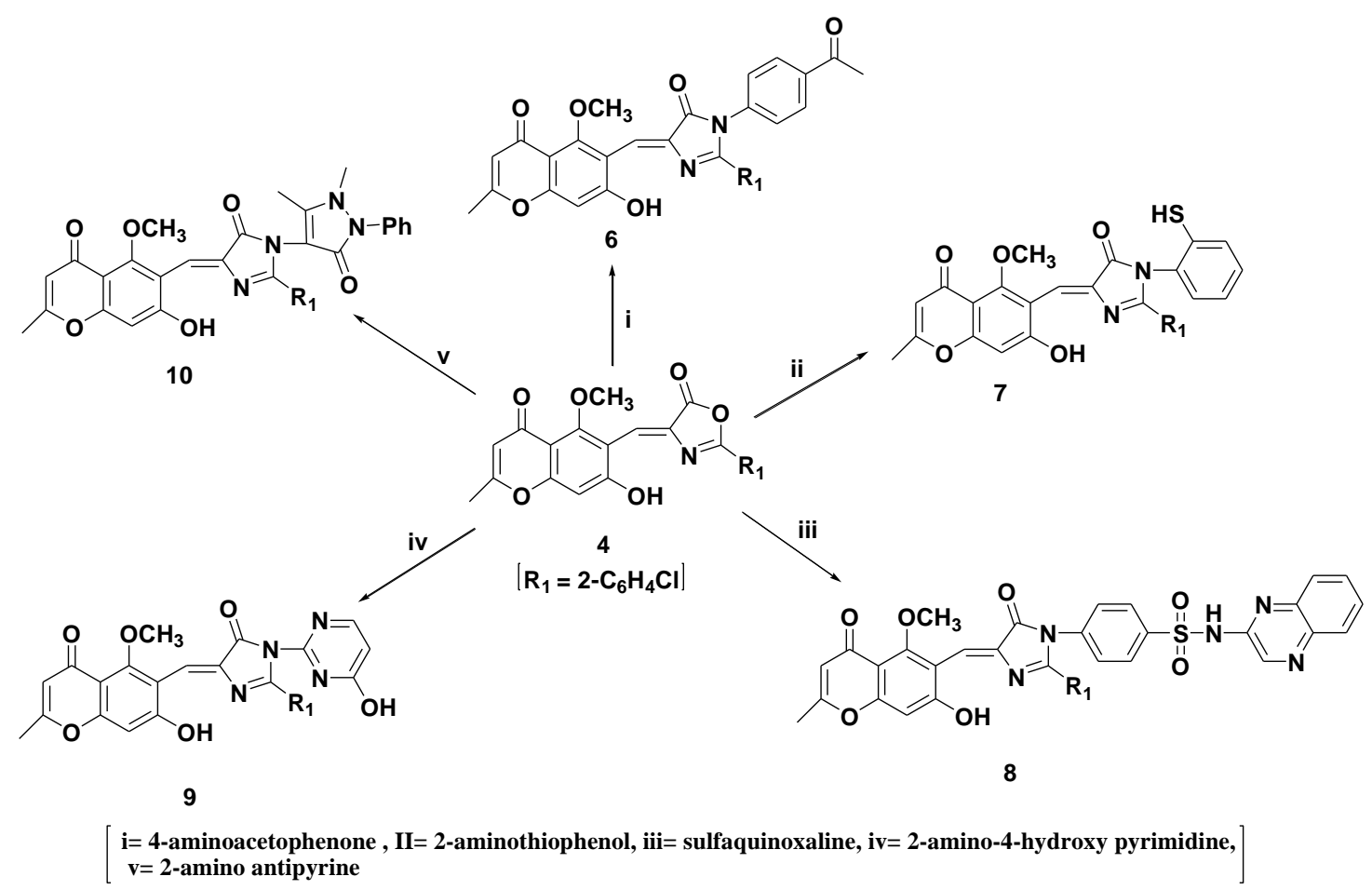

Scheme 3. Expected scheme for the different reactions of oxazole derivative with different amines.

Furthermore, treatment of compound 4 with formamide achieved 2-(2-chlorophenyl)4-((7-hydroxy-5-methoxy-2-methyl-4-oxo-4H-chromen-6-yl)methylene)-1H-imidazol-

5(4H)-one 11. Compound 4 reacted with hydrazine hydrate afforded 1-amino-2-(2chlorophenyl)-4-((7-hydroxy-5-methoxy-2-methyl-4-oxo-4H-chromen-6-yl)methylene)-1Himidazol-5(4H)-one 12, (Scheme 4). Compound 12 confirmed by IR spectrum which affords the imidazol carbonyl stretching frequency at $1701 \mathrm{~cm}^{-1}$, the coumarin carbonyl stretching at $1664 \mathrm{~cm}^{-1}$ and $\mathrm{NH}_{2}$ at 3328,3221 . Also, the structure 12 was supported by its mass spectrum which revealed a molecular ion peak at $\mathrm{m} / \mathrm{z} 425(22.55 \%)$ corresponding to the molecular formula $\mathrm{C}_{21} \mathrm{H}_{16} \mathrm{ClN}_{3} \mathrm{O}_{5}$.

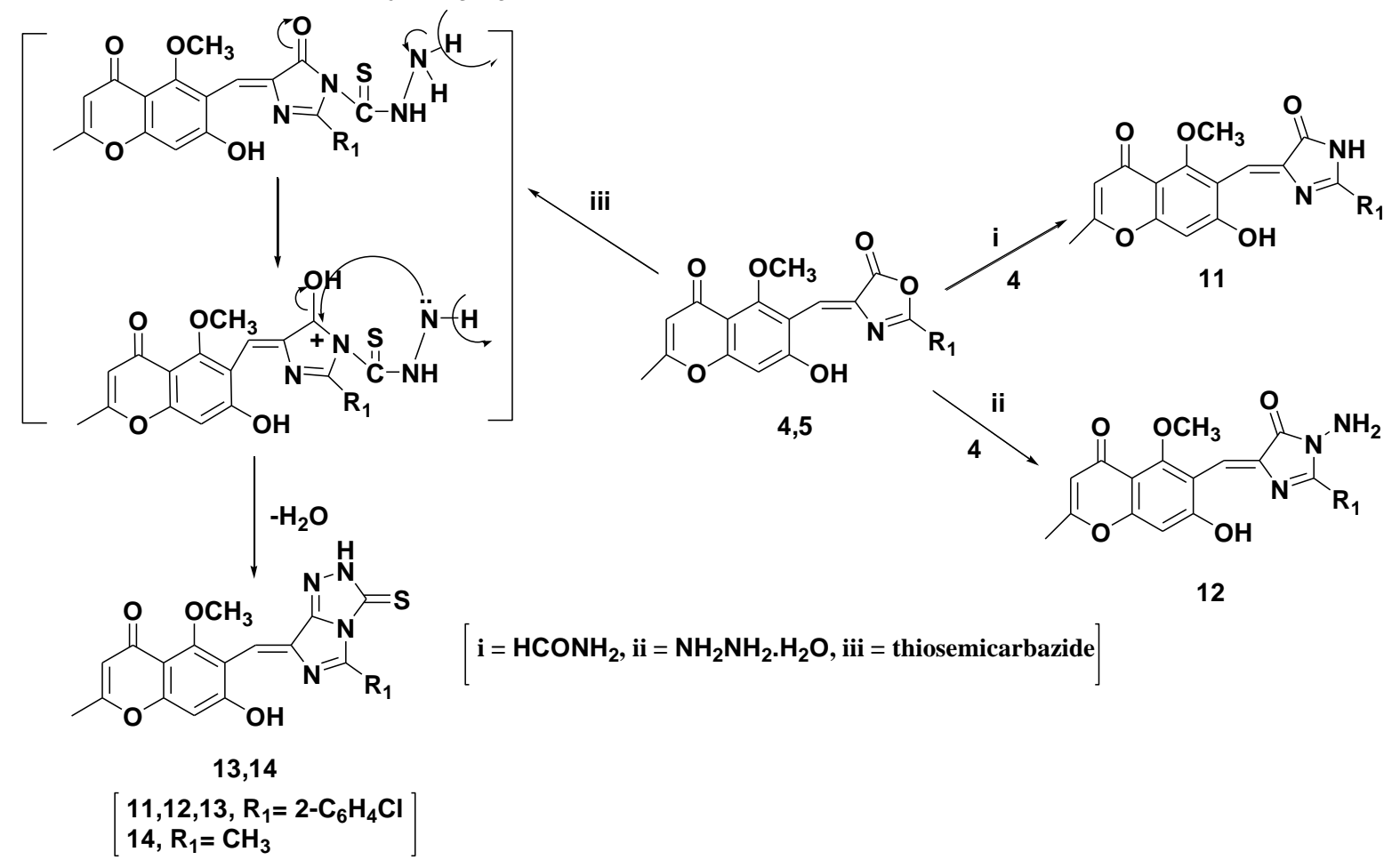


Scheme 4. Expected scheme for the reaction of oxazole derivatives with formamide and hydrazine hydrate and thiosemicarbazide.

Finally, treatment of oxazoles $\mathbf{4 , 5}$ with thiosemicarbazide afford imidazotriazole derivatives 13, 14, respectively. Compounds 13, 14 confirmed by IR spectra which revealed disappear the imidazol carbonyl stretching frequency and appear the coumarin carbonyl stretching frequency at 1632,1650 and $(\mathrm{C}=\mathrm{S})$ at 1568,1567 , respectively and presence of stretching broad band for $\mathrm{OH}$ group at $3432,3426 \mathrm{~cm}^{-1}$. Also, structures 13, 14 were supported by its mass spectrum and ${ }^{1} \mathrm{H}$ NMR spectra showed in experimental section. The formation of imidazotriazole derivatives $\mathbf{1 3}, \mathbf{1 4}$ is assumed to proceed through the in situ intramolecular cyclization of the non isolable intermediate via nucleophilic addition of the amino group to the carbonyl group followed by elimination of water, (Scheme 5).

\section{BIOLOGICAL ACTIVITIES}

\section{In virto anticancer screening}

Chemotherapy is a major therapeutic approach for the two human cultured cell lines which breast cancer cell and colon cancer cell lines (MCF7, HCT) in comparison to the known anti cancer drugs; doxorubicin and vinblastine as reference drugs, is one of the most effective antitumor agents used to produce regression in acute leukemias, Hodgkin's disease, and other lymphomas. The cytotoxic effects of the newly synthesized compounds were evaluated in the MCF7 breast cancer cell line with doxorubicin was used as a reference drug in six different concentrations. Also, HCT colon cancer cell line with vinblastine was used as a reference drug in three different concentrations. The primary anticancer assay was performed in accordance with the protocol of the Drug Evaluation Branch (Wasylyk, et al., 2008; Wilson and Bottiglier, 1962). From the results obtained in table1, the relationship between surviving fraction and drug concentration was plotted to obtain the survival curve of the MCF7 breast cancer cell line and another of the HCT colon cancer cell line. The response parameter calculated was the $\mathrm{IC}_{50}$ value which corresponds to the compound concentration causing 50\% mortality in net cells as depicted in Table 1 . In the new work, seven of the newly synthesized compounds $2,6,7,8,9,10,13,14$ were selected. The most of the screened compounds showed interesting cytotoxic activities compared to a reference drug, according to $\mathrm{IC}_{50}$ (which concentration causing $50 \%$ inhibition of cell growth. Chemotherapy is a major therapeutic for the both localized and metastasized cancers. Covering all structural variations in these analogs, being of tetrahydropyrano[3,2$b$ ]xanthene-4,7-dione 2 on colon cell line HCT was more active compound $\left(\mathrm{IC}_{50}: 3.1 \mu \mathrm{g} / \mathrm{ml}\right.$ ) and was found to be near to a reference drug (Doxorubicin, $\mathrm{IC}_{50}: 3.7 \mu \mathrm{g} / \mathrm{ml}$ ). However the activity of compound 2 against MCF7 was $\left(\mathrm{IC}_{50}: 4.2 \mu \mathrm{g} / \mathrm{ml}\right.$ ) has near to a reference drug (vinblastine $\mathrm{IC}_{50}: 2.97 \mu \mathrm{g} / \mathrm{ml}$ ). Imidazole moiety attached to mercaptophenyl derivative 7 $\left(\mathrm{IC}_{50}: 6.63 \mu \mathrm{g} / \mathrm{ml}\right)$ or to imidazotriazole derivatives $13\left(\mathrm{IC}_{50}: 7.85 \mu \mathrm{g} / \mathrm{ml}\right)$ and $14\left(\mathrm{IC}_{50}: 6.9\right.$ $\mu \mathrm{g} / \mathrm{ml})$ have moderate activity which have one half that of doxorubicin $\left(\mathrm{IC}_{50}: 3.743 \mu \mathrm{g} / \mathrm{ml}\right)$ against HCT. For MCF7, compound 7 (IC $50: 8.5 \mu \mathrm{g} / \mathrm{ml}$ ), compound $\mathbf{1 3}\left(\mathrm{IC}_{50}: 9.2 \mu \mathrm{g} / \mathrm{ml}\right.$ ) and compound $14\left(\mathrm{IC}_{50}: 8.8 \mu \mathrm{g} / \mathrm{ml}\right)$ which have one third that of vinblastine $\left(\mathrm{IC}_{50}: 2.97 \mu \mathrm{g} / \mathrm{ml}\right)$ according to the presence of mercapto group. The antitumor activity of another compounds containing hetero atom as compound $8\left(\mathrm{IC}_{50}: 10.5 \mu \mathrm{g} / \mathrm{ml}\right.$ for $\mathrm{MCF} 7,\left(\mathrm{C}_{50}: 11.2 \mu \mathrm{g} / \mathrm{ml}\right.$ for HCT), compound 9 ( $\mathrm{IC}_{50}: 10.9 \mu \mathrm{g} / \mathrm{ml}$ for MCF7, $\mathrm{IC}_{50}: 12.3 \mu \mathrm{g} / \mathrm{ml}$ for HCT) and compound $10\left(\mathrm{IC}_{50}: 12 \mu \mathrm{g} / \mathrm{ml}\right.$ for MCF7, IC $50: 12.8 \mu \mathrm{g} / \mathrm{ml}$ for HCT) have one forth activity against MCF7 which that of vinblastine $\left(\mathrm{IC}_{50}: 2.97 \mu \mathrm{g} / \mathrm{ml}\right.$ ) and against $\mathrm{HCT}$ which have one third that of doxorubicin $\left(\mathrm{IC}_{50}: 3.743 \mu \mathrm{g} / \mathrm{ml}\right)$ respectively. All have signification value according to presence of quinoxaline, pyrimidine and pyrazole moiety. Also compound 6 ( $\mathrm{IC}_{50}: 14$ $\mu \mathrm{g} / \mathrm{ml}$ for MCF7, $\mathrm{IC}_{50}: 13.3 \mu \mathrm{g} / \mathrm{ml}$ for HCT) containing acetylphenyl group has less activity 
compare to the six compounds but has considering value against to antitumor activity. Furthermore, all testing compounds gave antitumor activity against colon cancer cell HCT more than the activity against breast cancer cell MCF7. Finally, the decreasing order of growth inhibitory activities against breast cancer cell MCF7 and colon cancer cell HCT in comparison to the known anticancer drugs are 2>14 >13 $>7>8>9>10>6$. Table (1).

\section{CONCLUSIONS}

In this study, seven of the newly synthesized compounds $\mathbf{2 , 6 , 7 , 8 , 9 , 1 0 , 1 3 , 1 4}$ were selected to evaluation their in vitro growth inhibitory activities against breast cancer cell MCF7 and colon cancer cell HCT in comparison to the known anticancer drugs: doxorubicin and vinblastine as reference drugs. In virto growth inhibitory activities of imidazole derivatives against MHF7 and HCT cell lines revealed significant potential antitumor activity. Best results were gained by compound $\mathbf{2}$ since it showed approximately similar potency against MCF7 and HCT respectively. Chromone derivatives containing Imidazole moiety attached to mercaptophenyl 7 or to imidazotriazole derivatives $\mathbf{1 3 , 1 4}$ is moderate activity according to the presence of mercapto group. Hetero compounds as 7, 8 and 9 have signification value according to presence of quinoxaline, pyrimidine and pyrazole groups. Also, compound $\mathbf{6}$ containing acetylphenyl group has considerting value to antitumor activity. There is provided chromone derivatives of the general formula which an antitumor pharmaceutical composition comprising as an effective ingredient the novel chromone derivatives.

\section{EXPERIMENTAL}

\section{General methods}

Melting points were determined on a Stuart melting point apparatus. IR spectra were recorded on a Shimadzu-440 IR spectrophotometer using the $\mathrm{KBr}$ technique (Shimadzu, Japan). NMR spectra were measured on a Bruker Avance $300(300 \mathrm{~Hz})$ in DMSO- $d_{6}$ as a solvent, using tetramethylsilane (TMS) as an internal standard. The mass spectra were recorded on Shimadzu GCMS-QP-1000EX mass spectrometers at $70 \mathrm{eV}$. Elemental analyses were carried out by the Micro-analytical Research Centre, Cairo University. Analytical results for $\mathrm{C}, \mathrm{H}$ and $\mathrm{N}$ were within $\pm 0.4 \%$ of the calculated values. All reagents were of commercial quality and used without purification, follow up of the reaction and checking the purity of the compounds.

\section{7-hydroxy-5-methoxy-2-methyl-4-oxo-4H-chromene-6-carbaldehyde 1 was prepared} according to the literature procedures (Kepe, et al., 1993).

\section{5-methoxy-2,9,9-trimethyl-8,9,10,10a-tetrahydropyrano[3,2-b]xanthene-4,7-dione 2.}

A mixture of 1 (0.01 mol) and cyclic active methylene compound as 5, 5dimethylcyclohexane-1,3-dione $(0.01 \mathrm{~mol})$ in ethanol $(50 \mathrm{~mL})$ and catalytic amount of triethylamine $(0.5 \mathrm{~mL})$ was heated under reflux for $3 \mathrm{~h}$. The reaction mixture was poured onto ice water, collected, dried and solid was crystallized from the proper solvent to give 2 as yellow crystals. Yield: $80 \%$; m.p. $166-168^{0} \mathrm{C}$; IR $\left(\mathrm{KBr}, \mathrm{cm}^{-1}\right)$ : disappear of $\mathrm{OH}$ and the presence of two $\mathrm{C}=\mathrm{O}$ groups at 1657,1723 in added to 2953 ( $\mathrm{CH}$ aliph.), 3076 ( $\mathrm{CH}$ arom.), MS, $m / z(\%): 340[\mathrm{M}]$ (9.72), 52.3 (100), ${ }^{1} \mathrm{H}$ NMR (DMSO- $\left.d_{6}, 300 \mathrm{MHz}\right): \ddot{a} 1.17$ [s, 6H, $\left.2 \mathrm{CH}_{3}\right], 1.5\left[\mathrm{~s}, 2 \mathrm{H}, \mathrm{C}_{10} \mathrm{H}\right], 1.98\left[\mathrm{~s}, 3 \mathrm{H}, \mathrm{CH}_{3}\right], 2.9\left[\mathrm{~s}, 2 \mathrm{H}, \mathrm{C}_{8} \mathrm{H}\right], 3.9$ [s, 3H, $\left.\mathrm{OCH}_{3}\right], 6.13-7.79$ [m, 4H, Ar-H]. Anal. Calcd. for $\mathrm{C}_{20} \mathrm{H}_{20} \mathrm{O}_{5}: \mathrm{C}, 70.57 \%$; H, 5.92\%; O, 23.50\%; Found: C, $70.64 \%$; H, 5.99\%; O, $23.56 \%$. 


\section{2-(2-chlorophenyl)-4-((7-hydroxy-5-methoxy-2-methyl-4-oxo-4H-chromen-6- yl)methylene) oxazol-5(4H)-one 4.}

A mixture of $1(0.01 \mathrm{~mol}), o$-chlorobenzoylglycine $(0.01 \mathrm{~mol})$ and fused sodium acetate $(0.03 \mathrm{~mol})$ in acetic acid $(10 \mathrm{~mL})$ and acetic anhydride $(10 \mathrm{~mL})$ was heated on a steam bath for $3 \mathrm{~h}$. The reaction mixture was poured into a cold mixture of ethanol-water $(1: 1)(50 \mathrm{~mL})$ and stirred for $15 \mathrm{~min}$. The solid product was filtrated off, washed of water, dried and recrystallized from the proper solvent to give $\mathbf{4}$ as yellow crystals. Yield: 80\%,;m.p. 190$192^{\circ} \mathrm{C}$; IR ( $\left.\mathrm{KBr}, \mathrm{cm}^{-1}\right): 3423$ (br, OH), 3010 (CH arom.), 2984 ( $\mathrm{CH}$ aliph.), 1703, 1619 $(2 \mathrm{C}=\mathrm{O}), \mathrm{MS}, m / z(\%): 411$ [M-1] (5.16), 68.5 (100), ${ }^{1} \mathrm{H}$ NMR (DMSO- $\left.d_{6}, 300 \mathrm{MHz}\right): \ddot{a} 1.26$ $\left[\mathrm{s}, 3 \mathrm{H}, \mathrm{CH}_{3}\right], 3.93\left[\mathrm{~s}, 3 \mathrm{H}, \mathrm{OCH}_{3}\right], 6.13-8.19[\mathrm{~m}, 7 \mathrm{H}, \mathrm{Ar}-\mathrm{H}], 10.34$ [s, 1H, OH]. Anal. Calcd. for $\mathrm{C}_{21} \mathrm{H}_{14} \mathrm{ClNO}_{6}: \mathrm{C}, 61.25 \% ; \mathrm{H}, 3.43 \%$; N, 3.40\%; Found: C, $61.34 \% ; \mathrm{H}, 3.46 \%$; N, 3.45\%.

\section{4-((7-hydroxy-5-methoxy-2-methyl-4-oxo-4H-chromen-6-yl)methylene)-2-methyloxazol- $5(4 H)$ one 5.}

A mixture of $1(0.01 \mathrm{~mol})$, acetyl glycine $(0.01 \mathrm{~mol})$ and fused sodium acetate $(0.03 \mathrm{~mol})$ in acetic acid $(10 \mathrm{~mL})$ and acetic anhydride $(10 \mathrm{~mL})$ was heated on a steam bath for $3 \mathrm{~h}$. The reaction mixture was then poured into a cold mixture of ethanol-water $(1: 1)(50 \mathrm{~mL})$ and stirred for $15 \mathrm{~min}$. The solid product was filtrated off, washed of water, dried and recrystallized from the proper solvents to give $\mathbf{5}$ as yellow crystals. Yield: $90 \%$; m.p. 170$172^{0} \mathrm{C}$; IR ( $\left.\mathrm{KBr}, \mathrm{cm}^{-1}\right): 3363$ (br, OH), 3008 (CH arom.), 2994 ( $\mathrm{CH}$ aliph.), 1710, 1617 $(2 \mathrm{C}=\mathrm{O}), \mathrm{MS}, m / z(\%): 315$ [M] (6.04), 166 (100), ${ }^{1} \mathrm{H}$ NMR (DMSO- $\left.d_{6}, 300 \mathrm{MHz}\right): \ddot{a} 1.19$ [s, $\left.3 \mathrm{H}, \mathrm{CH}_{3}\right], 1.41\left[\mathrm{~s}, 3 \mathrm{H}, \mathrm{CH}_{3}\right], 3.93\left[\mathrm{~s}, 3 \mathrm{H}, \mathrm{OCH}_{3}\right], 6.53-8.21[\mathrm{~m}, 7 \mathrm{H}, \mathrm{Ar}-\mathrm{H},=\mathrm{CH}], 10.26[\mathrm{~s}$, $1 \mathrm{H}, \mathrm{OH}$. Anal. Calcd. for $\mathrm{C}_{16} \mathrm{H}_{13} \mathrm{NO}_{6}$ : C, $60.95 \%$; $\mathrm{H}, 4.16 \%$;, $4.44 \%$; Found: $\mathrm{C}, 60.87 \%$; $\mathrm{H}, 4.06 \%$; N, $4.39 \%$.

\section{General procedure 2-(2-chlorophenyl)-4-((7-hydroxy-5-methoxy-2-methyl-4-oxo-4H- chromen -6-yl)methylene)substituted-1H-imidazol-5(4H)-one 6-10.}

A mixture of 4 (0.01 mol) and aromatic amines namely: 4-amino-acetophenone i , Oaminothiophenol ii or hetero-aromatic amines as sulfaquionoxaline iii , 2-amino-4-hydroxypyrimidine iv and 4-aminoantipyrine $\mathrm{v}(0.01 \mathrm{~mol})$ and fused sodium acetate $(0.03 \mathrm{~mol})$ in glacial acetic acid $(30 \mathrm{~mL})$ was heated under reflux for $1 \mathrm{~h}$, then cooled. The reaction mixture was poured onto cold water. The solid products were filtrated off, washed of water, dried and recrystallized from the proper solvents to give 6-10 respectively.

\section{1-(4-acetylphenyl)-2-(2-chlorophenyl)-4-((7-hydroxy-5-methoxy-2-methyl-4-oxo-4H- chromen-6-yl)methylene)-1H-imidazol-5(4H)-one 6.}

Brown crystals; Yield: $60 \%$; m.p.270-272 ${ }^{0} \mathrm{C}$; IR $\left(\mathrm{KBr}, \mathrm{cm}^{-1}\right): 3362$ (br, OH), $3078(\mathrm{CH}$ arom.), 2920 (CH aliph.), 1730, 1665 (2C=O), MS, $m / z$ (\%): 528 [M-1] (5.15), $138(100),{ }^{1} \mathrm{H}$ NMR (DMSO- $\left.d_{6}, 300 \mathrm{MHz}\right): \ddot{a} 1.81\left[\mathrm{~s}, 3 \mathrm{H}, \mathrm{CH}_{3}\right], 2.24\left[\mathrm{~s}, 3 \mathrm{H}, \mathrm{COCH}_{3}\right], 3.89\left[\mathrm{~s}, 3 \mathrm{H}, \mathrm{OCH}_{3}\right]$, 6.32-8.21 [m, $11 \mathrm{H}, \mathrm{Ar}-\mathrm{H},=\mathrm{CH}], 10.56[\mathrm{~s}, 1 \mathrm{H}, \mathrm{OH}]$. Anal. Calcd. for $\mathrm{C}_{29} \mathrm{H}_{21} \mathrm{ClN}_{2} \mathrm{O}_{6}$ : C, $65.85 \%$; H, 4.00\%; N, 5.30\%; Found: C, 65.80\%; H, 3.93\%; N, 5.22\%.

\section{2-(2-chlorophenyl-4-((7-hydroxy-5-methoxy-2-methyl-4-oxo-4H-chromen-6- yl)methylene)-1-(2-mercaptophenyl)-1H-imidazol-5(4H)-one 7.}

Black crystals; Yield: 65\%; m.p.240-242 ${ }^{0} \mathrm{C}$; IR $\left(\mathrm{KBr}, \mathrm{cm}^{-1}\right): 3444$ (br, OH), $3078(\mathrm{CH}$ arom.), 2924 (CH aliph.), 1729, 1645 (2C=O). SH (1523), MS, m/z (\%): 518 [M] (7.10), 138 (100), ${ }^{1} \mathrm{H}$ NMR (DMSO- $\left.d_{6}, 300 \mathrm{MHz}\right): \ddot{a} 1.62\left[\mathrm{~s}, 3 \mathrm{H}, \mathrm{CH}_{3}\right], 3.91\left[\mathrm{~s}, 3 \mathrm{H}, \mathrm{OCH}_{3}\right], 5.04[\mathrm{~s}, 1 \mathrm{H}$, $\mathrm{SH}$ ], 6.53-8.91 [m, 11H, Ar-H, $=\mathrm{CH}], 10.56$ [s, $1 \mathrm{H}, \mathrm{OH}]$. Anal. Calcd. for $\mathrm{C}_{27} \mathrm{H}_{19} \mathrm{ClN}_{2} \mathrm{O}_{5} \mathrm{~S}$ : C, 62.49\%; H, 3.69\%; N, 5.40\%; Found: C, 62.43\%; H, 3.62\%; N, 5.24\%. 
4-(2-(2-chlorophenyl)-4-((7-hydroxy-5-methoxy-2-methyl-4-oxo-4H-chromen-6yl)methylene)-5-oxo-4,5-dihydroimidazol-1-yl)-N-(quinoxalin-2-yl)benzenesulfonamide 8.

Yellow crystals; Yield: $55 \%$; m.p. $170-172^{0} \mathrm{C}$; IR $\left(\mathrm{KBr}, \mathrm{cm}^{-1}\right): 3441$ (br, OH), $3360(\mathrm{NH})$, 3080 (CH arom.), 2920 ( $\mathrm{CH}$ aliph.), 1731, 1666 (2C=O), 1310, $1170\left(\mathrm{SO}_{2}\right), \mathrm{MS}, \mathrm{m} / z(\%)$ : 692 [M-2] (38), 139 (100), ${ }^{1} \mathrm{H}$ NMR (DMSO-d, $\left.300 \mathrm{MHz}\right): \ddot{a} 1.96$ [s, 3H, $\left.\mathrm{CH}_{3}\right], 3.99$ [s, 3H, $\left.\mathrm{OCH}_{3}\right], 5.1$ [s, 1H, CH-quinoxaline], 6.94-8.91 [m, 11H, Ar-H, =CH], $10.48[\mathrm{~s}, 1 \mathrm{H}, \mathrm{OH}]$, 11.56 [s, $1 \mathrm{H}, \mathrm{NHSO}_{2}$ ]. Anal. Calcd. for $\mathrm{C}_{35} \mathrm{H}_{24} \mathrm{ClN}_{5} \mathrm{O}_{7} \mathrm{~S}: \mathrm{C}, 60.56 \% ; \mathrm{H}, 3.49 \%$; N, $10.09 \%$; Found: C, 60.48\%; H, 3.42\%; N, 9.96\%.

2-(2-chl-orophenyl)-4-((7-hydroxy-5-methoxy-2-methyl-4-oxo-4H-chromen-6yl)methylene)-1-(4-hydroxypyrimidin-2-yl)-1H-imidazol-5(4H)-one 9.

Yellow crystals; Yield 60\%; m.p. 200-202 ${ }^{0} \mathrm{C}$; IR (KBr, cm $\left.{ }^{-1}\right): 3431$ (br, OH), $3009(\mathrm{CH}$ arom.), 2920 (CH aliph.), 1730, 1649 (2C=O), MS, m/z (\%): $505[\mathrm{M}+1](24), 69(100),{ }^{1} \mathrm{H}$ NMR (DMSO- $\left.d_{6}, 300 \mathrm{MHz}\right): \ddot{a} 1.57\left[\mathrm{~s}, 3 \mathrm{H}, \mathrm{CH}_{3}\right], 3.95\left[\mathrm{~s}, 3 \mathrm{H}, \mathrm{OCH}_{3}\right], 6.26-6.32[\mathrm{~d}, 2 \mathrm{H}$, CH-pyrimidine ], 6.79-7.91 [m, 7H, Ar-H, =CH], 10.01, 10.56 [2s, 2H, 2OH]. Anal. Calcd. for $\mathrm{C}_{25} \mathrm{H}_{17} \mathrm{ClN}_{4} \mathrm{O}_{6}$ : C, 59.47\%; H, 3.39\%; N, 11.10\%; Found: C, 59.42\%; H, 3.21\%; N, $10.96 \%$.

\section{4-(2-(2-chlorophenyl)-4-((7-hydroxy-5-methoxy-4-oxo-4H-chromen-6-yl)methylene)-5- oxo-4,5-dihydroimidazol-1-yl)-1,5-dimethyl-2-phenyl-1,2-dihydropyrazol-3-one 10.}

Yellow crystals; Yield: 48\%; m.p. 210-212 ${ }^{0} \mathrm{C}$; IR $\left(\mathrm{KBr}, \mathrm{cm}^{-1}\right): 3433$ (br, OH), $3023(\mathrm{CH}$ arom.), 2914 (CH aliph.), 1717, 1643 (2C=O), MS, m/z (\%): 598 [M+2] (13.9), 139 (100), ${ }^{1} \mathrm{H}$ NMR (DMSO- $\left.d_{6}, 300 \mathrm{MHz}\right): \ddot{a} 1.14,1.23$ [2s, 6H, 2CH 3 ], $3.81\left[\mathrm{~s}, 3 \mathrm{H}, \mathrm{N}-\mathrm{CH}_{3}\right], 3.96[\mathrm{~s}$, $\left.3 \mathrm{H}, \mathrm{OCH}_{3}\right], 6.32-8.96[\mathrm{~m}, 12 \mathrm{H}, \mathrm{Ar}-\mathrm{H}], 10.56[\mathrm{~s}, 1 \mathrm{H}, \mathrm{OH}]$. Anal. Calcd. for $\mathrm{C}_{32} \mathrm{H}_{25} \mathrm{ClN}_{4} \mathrm{O}_{6}$ : C, 64.38\%; H, 4.22\%; N, 9.38\%; Found: C, 64.27\%; H, 4.16\%; N, 9.29\%.

\section{2-(2-chlorophenyl)-4-((7-hydroxy-5-methoxy-2-methyl-4-oxo-4H-chromen-6-} yl)methylene)-1H-imidazol-5(4H)-one 11.

A solution of $4(0.01 \mathrm{~mol}$.) in formamide $(10 \mathrm{ml}$.) was refluxed for $5 \mathrm{~h}$. The solid obtained was crystallized from dioxane to give 11 as black crystals. Yield: $65 \%$; m.p. $280-282^{\circ} \mathrm{C}$; IR $\left(\mathrm{KBr}, \mathrm{cm}^{-1}\right)$ : 3414 (br OH, NH), 3060 ( $\mathrm{CH}$ arom.), 2922 (CH aliph.), $1640(\mathrm{C}=\mathrm{O}),{ }^{1} \mathrm{H}$ NMR (DMSO- $d_{6}, 300 \mathrm{MHz}$ ): $\ddot{a} 1.63$ [s, 3H, $\left.\mathrm{CH}_{3}\right], 3.36$ [s, 3H, $\left.\mathrm{OCH}_{3}\right], 6.13-7.97[\mathrm{~m}, 7 \mathrm{H}, \mathrm{Ar}-\mathrm{H}$, $=\mathrm{CH}], 10.02[\mathrm{~s}, 1 \mathrm{H}, \mathrm{OH}], 11.19$ [s, $1 \mathrm{H}, \mathrm{NH}]$. Anal. Calcd. for $\mathrm{C}_{21} \mathrm{H}_{15} \mathrm{ClN}_{2} \mathrm{O}_{5}: \mathrm{C}, 61.40 \% ; \mathrm{H}$, $3.68 \%$; N, 6.82\%; Found: C, 61.38\%; H, 3.62\%; N, 6.76\%.

\section{1-amino-2-(2-chlorophenyl)-4-((7-hydroxy-5-methoxy-2-methyl-4-oxo-4H-chromen-6-yl) methylene)-1H-imidazol-5(4H)-one 12.}

A mixture of $4(0.01 \mathrm{~mol})$ and hydrazine hydrate $(0.02 \mathrm{~mol})$ in ethanol $(20 \mathrm{~mL})$ was refluxed for $3 \mathrm{hrs}$, then allowed to cool. The solid precipitate was collected and recrystallized from the proper solvents to give 12 as yellow crystals. Yield: $60 \%$; m.p. Up to $300{ }^{0} \mathrm{C}$; IR $\left(\mathrm{KBr}, \mathrm{cm}^{-}\right.$ $\left.{ }^{1}\right): 3414,3328,3221$ (br OH, $\left.\mathrm{NH}_{2}\right), 3060$ (CH arom.), 2922 (CH aliph.), 1732, $1640(2 \mathrm{C}=\mathrm{O})$, MS, $m / z(\%): 425[\mathrm{M}](8.25), 166$ (100), ${ }^{1} \mathrm{H}$ NMR (DMSO- $\left.d_{6}, 300 \mathrm{MHz}\right): \ddot{a} 1.9$ [s, $\left.3 \mathrm{H}, \mathrm{CH}_{3}\right]$, $3.39\left[\mathrm{~s}, 3 \mathrm{H}, \mathrm{OCH}_{3}\right], 5.8\left[\mathrm{~s}, 2 \mathrm{H}, \mathrm{NH}_{2}\right], 6.23[\mathrm{~s}, 1 \mathrm{H},=\mathrm{CH}], 7.24-8.32[\mathrm{~m}, 8 \mathrm{H}, \mathrm{Ar}-\mathrm{H}], 10.98[\mathrm{~s}$, $1 \mathrm{H}, \mathrm{OH}$. Anal. Calcd. for $\mathrm{C}_{21} \mathrm{H}_{16} \mathrm{ClN}_{3} \mathrm{O}_{5}: \mathrm{C}, 59.23 \% ; \mathrm{H}, 3.79 \%$; N, 9.87\%; Found: C, $59.32 \%$; H, 3.73\%; N, 9.46\%.

\section{General procedure for Imidazo[5,1-c][1,2,4]triazol-7-ylidene)derivatives 13,14.}

To a solution of compound $\mathbf{4}$ or $\mathbf{5}(0.01 \mathrm{~mol})$ in dimethylformamide $(20 \mathrm{~mL})$ was added an equimolar amount of thiosemicarbazide $(0.01 \mathrm{~mol})$. The reaction mixture was heated under reflux for $8 \mathrm{~h}$, left over night, partially concentrated and cooled. The solid products were 
filtrated off, washed of water, dried and recrystallized from the proper solvents to give 13, 14 respectively.

\section{6-((5-(2-chlorophenyl)-3-mercapto-7H-imidazo[5,1-c][1,2,4]triazol-7-ylidene)methyl)-7- hydroxy-5-methoxy-2-methyl-4H-chromen-4-one 13.}

Brown crystals; Yield: 40\%; m.p. 220-222 ${ }^{0}$; IR $\left(\mathrm{KBr}, \mathrm{cm}^{-1}\right): 3414,3326,3286$ (br OH, $\mathrm{NH}), 3074$ (CH arom.), 2952 (CH aliph.), $1634(\mathrm{C}=\mathrm{O}), 1145(\mathrm{C}=\mathrm{S}), \mathrm{MS}, \mathrm{m} / z(\%): 467$ [M+1] (28.25), 138 (100) ${ }^{1} \mathrm{H}$ NMR (DMSO-d, $\left.300 \mathrm{MHz}\right): \ddot{a} 1.9\left[\mathrm{~s}, 3 \mathrm{H}, \mathrm{CH}_{3}\right], 3.34\left[\mathrm{~s}, 3 \mathrm{H}, \mathrm{OCH}_{3}\right]$, 6.03-7.49 [m, 7H, Ar-H, =CH], $10.04[\mathrm{~s}, 1 \mathrm{H}, \mathrm{OH}], 11.12$ [s, 1H, NH]. Anal. Calcd. for $\mathrm{C}_{22} \mathrm{H}_{15} \mathrm{ClN}_{4} \mathrm{O}_{4}$ : C, 56.59\%; H, 3.24\%; N, 12.00\%; Found: C, 56.64\%; H, 3.46\%; N, $12.17 \%$.

\section{7-hydroxy-5-methoxy-2-methyl-6-((5-methyl-3-thioxo-2,3-dihydroimidazo[5,1- c][1,2,4]triazol-7-ylidene)methyl)-4H-chromen-4-one 14.}

Brown crystals; Yield: 40\%; m.p. $198-200^{0} \mathrm{C}$; IR $\left(\mathrm{KBr}, \mathrm{cm}^{-1}\right): 3415,3331$ (br OH, NH), 3076 (CH arom.), 2972 (CH aliph.), $1654(\mathrm{C}=\mathrm{O}), 1567(\mathrm{C}=\mathrm{S}), \mathrm{MS}, \mathrm{m} / z(\%): 368$ [M-2] (8.25), 166 (100), ${ }^{1} \mathrm{H}$ NMR (DMSO- $\left.d_{6}, 300 \mathrm{MHz}\right): \ddot{a} 1.27\left[\mathrm{~s}, 3 \mathrm{H}, \mathrm{CH}_{3}\right], 1.48\left[\mathrm{~s}, 3 \mathrm{H}, \mathrm{CH}_{3}\right]$, $3.71\left[\mathrm{~s}, 3 \mathrm{H}, \mathrm{OCH}_{3}\right], 6.57[\mathrm{~d}, 1 \mathrm{H},=\mathrm{CH}], 7.52[\mathrm{~s}, 2 \mathrm{H}, 2 \mathrm{CH}], 10.45[\mathrm{~s}, 1 \mathrm{H}, \mathrm{OH}], 11.06[\mathrm{~s}, 1 \mathrm{H}$, $\mathrm{NH}$. Anal. Calcd. for $\mathrm{C}_{17} \mathrm{H}_{14} \mathrm{~N}_{4} \mathrm{O}_{4} \mathrm{~S}$ : C, 55.13\%; H, 3.81\%; N, 15.13\%; Found: C, 55.09\%; $\mathrm{H}, 3.75 \%$; N, $15.03 \%$.

\section{In-vitro anticancer evaluation}

\section{Materials and methods}

The human tumor cell lines (MCF7 and HCT) were available at the regional center for mycology \& biotechnology at Al-Azhar University, Cairo, Egypt. Mammalian cell lines: MCF7 and HCT cells (human cell line of a well differentiated breast and colon carcinoma isolated from a breast or colon biopsy of a male Caucasian aged 15 years) were obtained from the American Type Culture Collection (ATCC). Chemicals Used: Dimethyl sulfoxide (DMSO), crystal violet and trypan blue dye were purchased from Sigma (St. Louis, Mo., USA). Fetal Bovine serum, DMEM, RPMI-1640, HEPES buffer solution, L-glutamine, gentamycin and $0.25 \%$ Trypsin-EDTA were purchased from Lonza. Crystal violet stain (1\%): It composed of $0.5 \%(\mathrm{w} / \mathrm{v})$ crystal violet and $50 \%$ methanol then made up to volume with $\mathrm{dH}_{2} \mathrm{O}$ and filtered through a Whatmann No.1 filter paper.

\section{Procedure}

The cells were propagated in Dulbecco's modified Eagle's medium (DMEM) supplemented with $10 \%$ heat-inactivated fetal bovine serum, $1 \%$ L-glutamine, HEPES buffer and $50 \mu \mathrm{g} / \mathrm{ml}$ genta-mycin. All cells were maintained at $37^{\circ} \mathrm{C}$ in a humidified atmosphere with $5 \% \mathrm{CO}_{2}$ and were subcultured two times a week. Cell toxicity was monitored by determining the effect of the test samples on cell morphology and cell viability.

Cytotoxicity evaluation using viability assay (Mosmann, 1983 and Vijayan, 2004): For cytotoxicity assay, the cells were seeded in 96-well plate at a cell concentration of $1 \times 10^{4}$ cells per well in $100 \mu \mathrm{l}$ of growth medium. Fresh medium containing different concentrations of the test sample was added after $24 \mathrm{~h}$ of seeding. Serial two-fold dilutions of the tested chemical compound were added to confluent cell monolayers dispensed into 96-well, flatbottomed microtiter plates (Falcon, NJ, USA) using a multichannel pipette. The microtiter plates were incubated at $37^{\circ} \mathrm{C}$ in a humidified incubator with $5 \% \mathrm{CO}_{2}$ for a period of $48 \mathrm{~h}$. Three wells were used for each concentration of the test sample. Control cells were incubated without test sample and with or without DMSO. The little percentage of DMSO present in the wells (maximal $0.1 \%$ ) has no effect on the cell line. After incubation of the cells for $24 \mathrm{~h}$ at $37^{\circ} \mathrm{C}$, various concentrations of sample $(50,25,12.5,6.25,3.125 \& 1.56 \mu \mathrm{g})$ 
were added, and the incubation was continued for $48 \mathrm{~h}$ and viable cells yield was determined by a colorimetric method. In brief, after the end of the incubation period, media were aspirated and the crystal violet solution (1\%) was added to each well for at least 30 minutes. The stain was removed and the plates were rinsed using tap water until all excess stain is removed. Glacial acetic acid (30\%) was then added to all wells and mixed thoroughly, and then the absorbance of the plates were measured on Microplate reader (TECAN, Inc.), using a test wavelength of $490 \mathrm{~nm}$. All results were corrected for background absorbance detected in wells without added stain. Treated samples were compared with the cell control in the absence of the tested compounds. All experiments were carried out in triplicate. The relation between surviving fraction and drug concentration was plotted to get the survival curve of each tumor cell line. The concentration required for $50 \%$ inhibition of cell viability $\left(\mathrm{IC}_{50}\right)$ was calculated and compared with the reference drug vinblastine and the results are given in table 1 .

Table 1. In-vitro anticancer evaluation against human tumor breast and colon cell lines (MCF7 and HCT).

\begin{tabular}{|rrr|}
\hline Cpd. No. & \multicolumn{1}{|c|}{$\mathbf{I C}_{\mathbf{5 0}}{ }^{\mathbf{a}, \mathbf{b}}(\boldsymbol{\mu g} \mathbf{g} \mathbf{m l})$} \\
$\mathbf{M F 7}$ & $\mathbf{H C T}$ \\
$\mathbf{2}$ & 3.1 & 4.2 \\
$\mathbf{6}$ & 14 & 13.3 \\
$\mathbf{7}$ & 8.5 & 6.63 \\
$\mathbf{8}$ & 10.5 & 11.2 \\
$\mathbf{9}$ & 10.9 & 12.3 \\
$\mathbf{1 0}$ & 12 & 12.8 \\
$\mathbf{1 3}$ & 9.2 & 7.85 \\
$\mathbf{1 4}$ & 8.8 & 6.9 \\
Doxorubicin & $\ldots \ldots$. & 3.743 \\
Vinblastine & 2.97 & $\ldots \ldots$ \\
\hline
\end{tabular}

\section{REFERENCE}

${ }^{\mathrm{a}} \mathrm{IC}_{50}$, compound concentration required to inhibit tumor cell proliferation by $50 \%$.

${ }^{\mathrm{b}}$ Values are means of three experiments.

Abdalla M.M., Abdel-Wahab B.F., Amr A.E., (2009): Monatsh Chem. 140, 129.

Abdel-Aziz H.A., Abdel-Wahab B.F., Badria F.A., (2010): Arch. Pharm. 343, 152.

Abdel-Wahab B.F., Abdel-Aziz H.A., Ahmed E.M., (2008): Arch.Pharm. 341734.

Abdel-Wahab B.F., Abdel-Aziz H.A., Ahmed E.M., (2009a): Eur. J. Med. Chem. 44 (2009) 2632.

Abdel-Wahab B.F., El-Ahl A.-A.S., Badria F.A., (2009b): Chem. Pharm. Bull. 57 (2009) 1348.

Al-Masoudi A., Al-Soud Y. A., Al-Salihi N. J., Al-Masoudi N. A., (2006): Chem. Het. Comp. 421377.

Amr A.E., Sabrry N.M., Abdalla M.M., Abdel-Wahab B.F., (2009): Eur. J. Med. Chem. 44 (2009) 725.

Aridoss G., Balasubramanian S., Parthiban P., Kabilan S., (20060: Eur. J. Med. Chem. 41, 268.

Bakr F. Abdel-Wahab, Ghada E.A. Awad, Farid A. Badria, (2011): Eur. J. Med. Chem. 461505.

Bhandari K., Srinivas N., Keshava G.B.S., Shukla P.K., (2009): Eur. J. Med. Chem. 44, 437.

Congio C., Cocco M.T., Onnis V., (2008): Bioorg. Med. Chem. Lett. 18, 989. 
Cui B., Zheng B. L., He K., Zheng Q. Y., (2003): J. Nat. Prod. 661101.

Emami S., Foroumadi A., Falahati M., Lotfali E., Rajabalian S., Ebrahimi S., Farahyar S., Shafiee A., (2008): Bioorg. Med. Chem. Lett. 18, 141.

Erlenmeyer E., Liebigs A., (1893): Ann.Chem. 1, 275.

Hose C. D., Hollingshead M., Sausville E. A., Monks A., (2003): Mol. Cancer. Ther. 2 1265.

Ivanov I. C., Glasnov T. N., Heber D., (2005): J. Heterocyclic Chem. 42, 857.

kepe V., Kocevar M., Petric A., Polanc S., Vercek B., (1992): Hetero-cycles. 33, 843.

kepe V., Kocevar M., Polanc S., (1993): Heterocycles. 35, 995.

Kepe V., Kozjan V., Polanc S., Kocevar M., (1999): Heterocycles. 50, 315.

Kumar D., Jacob M. R., Reynolds M. B., Kerwin S. M., (2002): Bioorg. Med. Chem. 10 3997.

Mulwad Z., Shirodkar Z. M., (2002): Indian. J. Chem. 41B, 1263.

Nagarapu L., Satyender A., Rajashaker B., Srinivas K., Rani P.R., Radhika K., Subhashini G., (2008): Bioorg. Med. Chem. Lett. 18, 1167.

Özkay Y., Isýkdag I., Incesu Z., Akalýn G., (2010): Eur. J. Med. Chem. 453320.

Padmavathi V., Prema kumari C., Venkatesh B. C., Padmaja A., (2011): Eur. J. Med. Chem. 46, 5317.

Perez-Ruixo J. J., Piotrovskij V., Zhang S., Hayes S., DePorre P., Zannikos P., (2006): Br. J. Clin. Pharmacol. 62, 81.

Smith R.C., Reeves J.C., (1987): Biochem. Pharmacol. 36, 1457.

Wasylyk C., Zheng H., Castell C., Debussche L., Multon M. C., Wasylyk B., (2008): Cancer Res. 68, 1275.

Wilson W. L., Bottiglier N. G., (1962): Cancer Chemother. 21 (1962) 137.

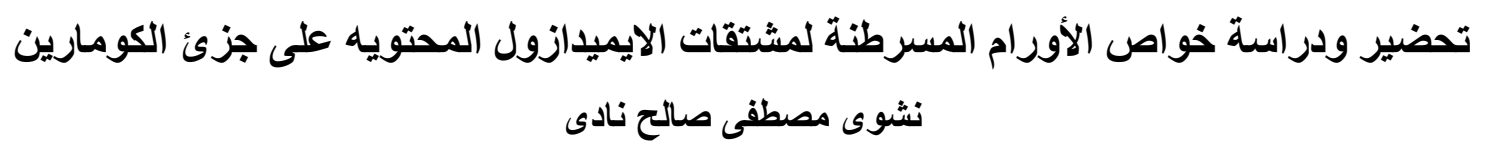

$$
\text { قسم الكيمياءـ كلية العلوم (بنات) جامعة الأزهر - القاهرة }
$$

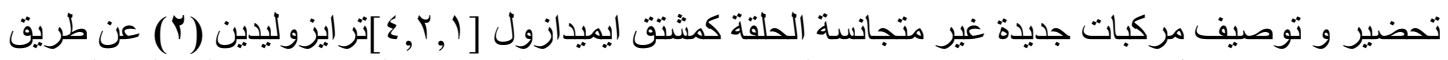

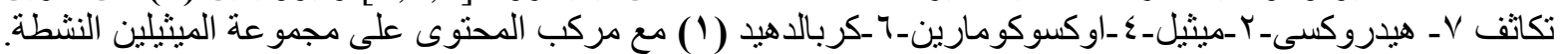

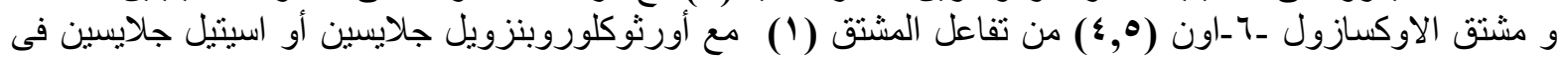

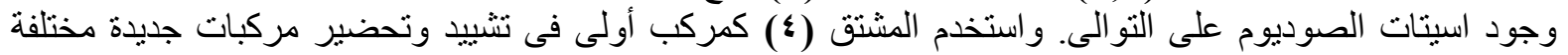

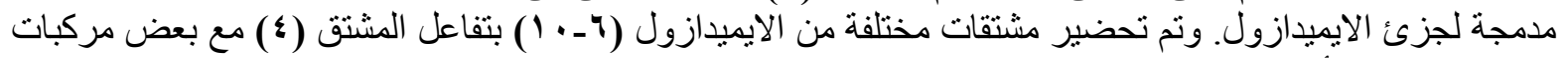

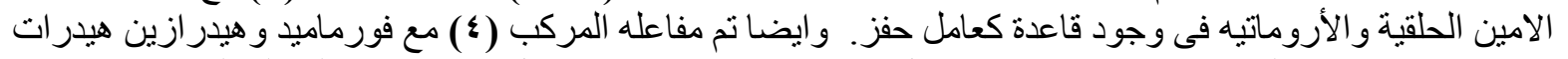

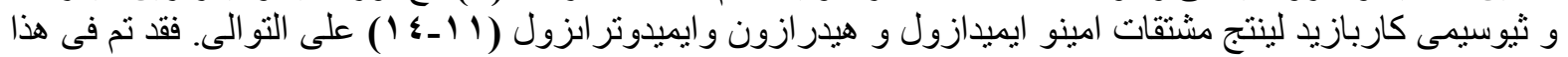

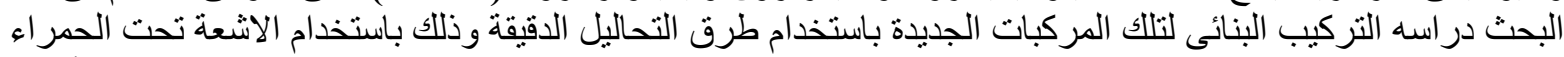

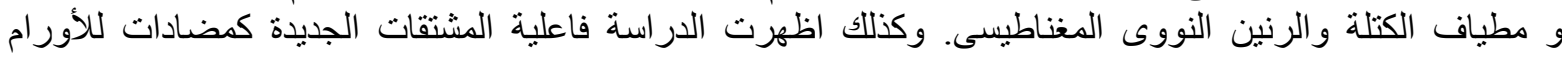

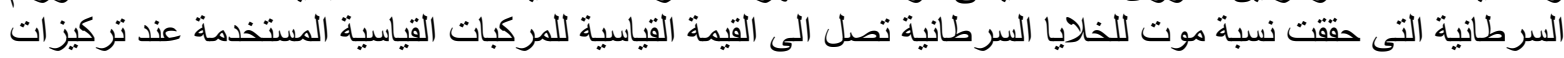

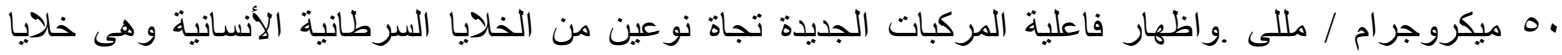

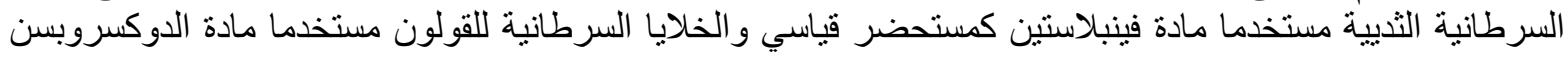

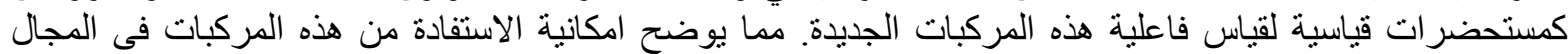

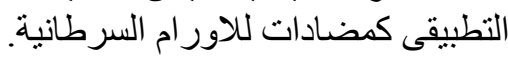

